This is a pre-print draft version of a published article.

To cite this article, see: Helen Macnaughtan (2012): An interview with Kasai Masae, captain of the Japanese women's volleyball team at the 1964 Tokyo Olympics, Japan Forum, 24:4, 491-500

To link to this article : http://dx.doi.org/10.1080/09555803.2012.729851

\title{
An interview with Kasai Masae Captain of the Japanese women's volleyball team at the 1964 Tokyo Olympics
}

\section{Helen Macnaughtan}

Keywords: women's volleyball, 1964 Tokyo Olympic Games, Nichibō Corporation

In the early evening of 23rd October 1964, people and taxis disappeared off the streets of Japan as almost everybody rushed to be near a television set to watch a women's volleyball match. The match was the final game of the women's volleyball competition in the 1964 Tokyo Olympics, a match between the Japanese and the USSR teams. The Japanese public had been buoyed by good results in judo, gymnastics and wrestling already in the 1964 Olympics, but to say that they now expected a gold medal from the home women's volleyball team was an understatement. One of the team members had commented anxiously the previous day that: 'if we lose, we might have to leave the country'. Such was the public expectation and pressure amounting on the players for this volleyball match. At $7 \mathrm{pm}$ that evening, the excitement emanating from the Komazawa indoor sports hall in Tokyo began its broadcast on televisions across Japan. The Japanese and the Soviet teams arrived onto the court. With Soviet players as tall as $184 \mathrm{~cm}$ in height, they looked a physically opposing presence vis-à-vis the Japanese team. Kasai Masae, the team captain, was the tallest Japanese player at $174 \mathrm{~cm}$. The Japanese team won the first two sets decisively: 15-11 and 15-8. In the third set they were leading 13-6, but then lost points consecutively as the pressure of winning the gold became closer to reality. When the score reached 14-13, their coach requested a time-out to talk to his team. After play resumed, the Japanese served the ball and an over the net foul from a Soviet player at 9:06pm secured the elusive $15^{\text {th }}$ point and served up Olympic history (final score: 15-11, 15-8, 15-13). As a new sport in the 1964 Games, it was the first gold medal in women's volleyball in Olympic history. For Japan, it was also the first Olympic gold medal for a women's event in 28 years. ${ }^{1}$ But it was also much more than a gold medal victory. For Japan, it was the culmination of a journey back on to the international stage after their WWII defeat, and a sporting event that served to unite and restore the spirit of a nation and its people. For the Japanese women's

\footnotetext{
${ }^{1}$ Hideko Maehata had won gold in 200m women's breaststroke at the 1936 Berlin Olympics; the first Japanese woman to win an Olympic gold medal.
} 
volleyball team, it was the end of a journey that had taken them from playing the sport as young employees in a Japanese company team to representing their nation at the first and only Summer Olympics to have ever been held in Japan ${ }^{2}$.

Tokyo had been awarded the rights to host the 1964 Games at an IOC meeting in May 1959. The city had previously been scheduled to host the 1940 Summer Olympics, but due to Japan's invasion of China the right to the 1940 Games was instead passed to Helsinki (and later cancelled altogether due to WWII). The 1964 Tokyo Games were the first Olympics held in Asia, as well as the first to be telecast internationally. It was also an Olympic first for women's volleyball. Although the Olympics had long comprised individual sports for women, women's ball games and team sports were adopted for the very first time at the 1964 Tokyo Olympics. The staging of the Games was a display in Japanese modern gadgetry and organisational skill. It also evolved to inspire pride and emotion across Japan. Symbolically, it represented an international acceptance that Japan was back on the post-war world stage, and had risen from the ashes of WWII in less than 20 years to be able to host the Olympics and be seen as a leading modern, technological nation. Japan would go on to win 16 gold medals (and a total of 29 medals), making it the third highest medal ranking nation behind the USA and the USSR for the 1964 Games. Despite some initial criticism and reluctance, the Japanese people gradually rallied around the Games. The opening ceremony on the $10^{\text {th }}$ October was watched by over $70 \%$ of the Japanese public, while the women's volleyball final on the 23 rd October, a day before the closing ceremony, was watched by $85-90 \%$ of Japanese, including an audience of some 4,000 at the match itself.

While researching women's volleyball from the perspective of its history as a corporate sport linked to the development of the Japanese textile industry, I got the opportunity to conduct an interview with the captain of the 1964 gold medal Olympic team, Kasai Masae. Kasai is still widely remembered in Japan and, at 79 years of age this year, still involved with volleyball and still has a sharp and lively memory for the detail of the 1964 events and her role in them. My aim in the interview was to ask her not only about the Olympic victory itself, but also ask about her life before and after 1964. As a basis for our interview, I read her memoir style book 'Mum's Gold Medal' (お母さんの金メダル) published in Japanese in 1992, which I now use as a source to introduce her story to readers here before presenting the interview itself. ${ }^{3}$

Kasai Masae was born in Yamanashi prefecture on 14th July 1933, and first started playing volleyball at secondary school in 1946, aged 13 years. She says she joined the volleyball team because she had thought the team adviser, a teacher at the school, was good looking. ${ }^{4}$ Two years later she was recruited into Nichibō, one of the Big Ten textile spinning companies in Japan at

\footnotetext{
2 Japan has hosted the Winter Olympic Games twice in Sapporo in 1972 and Nagano in 1998.

${ }^{3}$ Two key sources are used for this paper. The first is a semi-structured interview I conducted with Kasai on $30^{\text {th }}$ May 2012, the first interview she said she had given to a non-Japanese academic. The interview is transcribed and translated from the Japanese by myself. The second source is her book Kasai (1992) written in Japanese, and to my knowledge not used in any academic paper either in Japanese or English to date. Kasai, Masae (1992). お母さんの 金メダル (Mum's Gold Medal). Gakken.

${ }^{4}$ Kasai (1992:181)
} 
that time, ${ }^{5}$ after being scouted on the volleyball court. She had been spotted when her team participated in a Kanto regional tournament, as she was very tall and showed potential. ${ }^{6}$ A representative from Nichibō subsequently came to her parents' house offering her employment with the company. Kasai describes her parents as being overwhelmed and thankful for a visit from such a big corporation. Her parents accepted the company's offer, and she describes it as 'like a dream', as Nichibō had the strongest female volleyball team in Japan at that time. ${ }^{7}$ Kasai was initially recruited into the company's Sekigahara factory, but was moved to the Ashikaga (Tochigi) factory a month later, as the Ashikaga factory had the company's strongest volleyball team at that time. In 1953, Nichibō decided to unite all its factory volleyball teams and establish a new corporate team at their Kaizuka (Osaka) branch, so she was moved to Kaizuka in $1954 .{ }^{8}$ This unification of their volleyball teams was a strategy by the company to conquer in volleyball competitions nationally, and the Nichibō Kaizuka team indeed went on to become the strongest domestic women's team for several years. Volleyball training for this corporate women's team was intensified in line with this strategy from 1954, and a training regime known as 'murderous exercise' (殺人体操) was implemented by their coach, Daimatsu Hirobumi, who would also reach national notoriety by the time of the 1964 Olympics.

Kasai was one of three Nichibō players selected to first represent Japan in the sport abroad, on an expedition to China in 1957 to play six-a-side volleyball for the first time (prior to that nine-aside volleyball had been played). ${ }^{9}$ However, in 1960 the stakes changed. In that year, at 27 years of age, Kasai was a member of the first national Japanese women's volleyball team (essentially comprised of the Nichibō Kaizuka team) to participate in an international competition, the volleyball world championship held in Brazil that year. It was the first time for Japan to send both men's and women's teams to the world championships, and the women's team surprised everybody by taking second place in the competition, runners up to the USSR team. At the next world championships held in Moscow in 1962, the Japanese women won the competition, beating the Soviets in a surprise upset, as the Soviets were widely believed to be the world's strongest team and firm favourites for that competition. After that victory, the Japanese women's team was given the nickname ‘The Oriental Witches' (東洋の魔女) by the Russian media who suggested that the Japanese team had used some form of 'magic' to win. The next big battle for these two teams would be two years later in Tokyo at the 1964 Olympic Games.

\footnotetext{
${ }^{5}$ For a broader history of women working in the textile industry during these years, including details on recreational club activities for girls such as volleyball, see my earlier work: Macnaughtan, Helen (2005). Women, Work and the Japanese Economic Miracle: the case of the cotton textile industry, 1945-75. London, RoutledgeCurzon.

${ }^{6}$ Kasai $(1992: 182)$

${ }^{7}$ Kasai (1992:183)

${ }^{8}$ Kasai (1992:183-4)

${ }^{9}$ Kasai (1992:187)
} 
The final game in 1964 Olympics women's volleyball competition was, in the end, a decisive victory for the Japanese team, who won in three straight sets. ${ }^{10}$ At the moment of victory, the 4,000 spectators in the hall leapt to their feet with thunderous applause, while the six Japanese players on the court stood upright for a moment then cried and embraced each other. In her book, Kasai describes the moment the whistle blew in the final match, and her team mates cried and came to hug her. She writes that she was choked with deep emotion, and filled with tears but that she tried not to cry 'until her mission as team captain finished'. ${ }^{11}$ While receiving the gold medal in the awards ceremony and watching the Japanese flag raised to the national anthem, she says she felt very emotional and moved, and very happy that she had been able to meet the expectations from the Games audience and the Japanese people. However, the emotion of the win and the decision to play in that Olympic Games had clearly been a difficult personal decision and sacrifice for Kasai. Cited in the Yomuri newspaper the day after the victory, Kasai confessed that she had the feelings of any 'normal young woman'. She told how a good friend of hers from high school had come to the competition with her daughter to cheer on the team. Seeing her friend with an eight year old daughter, Kasai said she felt mixed feelings, thinking that if she hadn't continued with competitive volleyball she might have been in the audience with a child like her friend. Kasai's father had passed away in July of that year and had wanted to see her as a bride. Commenting on the victory after the match, Kasai was quoted as saying: 'I would like to choose a happy life as a woman from tomorrow, with my all experience of volleyball up until tonight'. ${ }^{2}$

After the Olympic victory, it is fair to say that Kasai became somewhat of a national celebrity in Japan. Although she comments that her wish was to retire immediately after the Olympic Games, she was very busy playing friendly games against Romania and in China. There were also a lot of celebration parties filling her life. ${ }^{13}$ In January 1965, when the women's team coach Daimatsu announced his decision to retire from Nichibō and from the national team, Kasai and five other players then also announced their resignation the following day. ${ }^{14}$ But even after these official retirements, the media continued to follow the lives of the players, particularly with regard to their possible marriage moves. Upon meeting the Prime Minister of the time soon after the victory, Daimatsu asked PM Sato to help arrange marriage introductions for his players. Mrs Sato duly introduced Kasai to her future husband, an officer in Japan's Self Defence Forces. Kasai records in her book how she was followed around by the media all the time after the Olympics; that it was difficult to meet up with her fiancé Mr Nakamura without the media noticing; and that six months after the Olympics she was still so busy every day that she felt she

\footnotetext{
10 The final results in the women's volleyball competition at the 1964 Tokyo Olympics was, in order of win: Japan, USSR, Poland, Romania, USA and South Korea. Although the Japanese men's volleyball team was not expected to win a medal, they took the bronze medal.

${ }^{11}$ Kasai (1992:90).

${ }^{12}$ Yomiuri Shinbun, Morning Edition, 24th October 1964.

${ }^{13}$ Kasai (1992:33)

${ }^{14}$ Kasai (1992:35)
} 
had little time to prepare for her wedding. ${ }^{15}$ Kasai's wedding to Nakamura in May 1965 made national media headlines in Japan. PM Sato and his wife attended the wedding as official matchmakers and the PM gave a speech at the wedding commenting: 'I think Kasai Masae is more well known than me in Japan'. The newlywed couple were interviewed on TV following their ceremony, and on their honeymoon to Hakone were followed around by several cars from the Japanese media. ${ }^{16}$

Kasai continued to be heavily involved in volleyball after retiring from the national team and from Nichibō Corporation. She was invited immediately after the Olympics, together with Coach Daimatsu, to China by Premier Zhou Enlai to help train up the Chinese male and female national teams. In 1965, she and other ex-Nichibō players formed Fuji Club, a women's volleyball team which went on to win the Japanese national tournament in 1965 and $1966 .{ }^{17}$ In 1973, a weekly television programme called 土曜デポルテ began, in which six of the original 'Oriental Witches' played against various amateur women's volleyball teams in the programme once a week, which helped contribute to the popularity and spread of the sport for women of all ages across Japan. ${ }^{18}$ During the 1980s and 1990s, Kasai has been a coach for various teams, including the so-called mothers' (mama-san) league. She was also Vice-Chair of the Japan Volleyball Association (JVA) in 2003-04, charged with strengthening Japanese women's volleyball, as well as heading the Japanese women's team at the 2004 Olympic Games in Athens. She was inducted into the Volleyball Hall of Fame in 2008.

The following is the transcript of my interview with her conducted on $30^{\text {th }}$ May, 2012.

Macnaughtan: You were recruited into Nichibō after graduating secondary school. What kind of job were you employed to do at Nichibō?

Kasai: I did a desk job in the office at Nichibō. I didn't work in the factory. I would work in the mornings, and then after lunch, from $3 \mathrm{pm}$ I would go to volleyball practice in the company gymnasium for several hours. In the early days, volleyball was not yet an Olympic event, and so our goal was to be the number one team in Japan. In 1960, the Japanese women's volleyball team participated in the world volleyball championship held in Brazil for the first time. Although it was our very first time to go to the world games in Brazil, we unexpectedly won second prize. That made us think that if we could beat the USSR team, then we could be number one in the world. After that world championship in 1960, our practice hours became much longer than before, until 2-3am every day. Before that, we hadn't practiced that late. Our practice changed, so that we could aim to not only be number one in Japan, but number one in the world. We wanted to beat the USSR team and win the next world championships in Moscow in 1962.

\footnotetext{
${ }^{15}$ Kasai (1992:24\&33)

${ }^{16}$ Kasai (1992:50-53)

${ }^{17}$ Kasai (1992:98)

${ }^{18}$ Kasai $(1992: 138 \& 140)$
} 
Macnaughtan: The other prominent textile companies (e.g. Kurabo and Toyobo) also had volleyball teams, but why do you think Nichibō in particular became so strong at women's volleyball?

Kasai: We did the most practice, and so we became the strongest team. Other companies like Kurabō, Tōyōbō and Kanebō were putting a lot of effort into their volleyball teams too, the same as Nichibō. But we really practiced hard. By the time I retired our team had won 185 games consecutively, and I was the team captain during all those games. After I retired, the team continued to win consecutively until their 257 th game. It was a winning streak of around seven and a half years.

Macnaughtan: How did you become so strong as a team? Was it the influence of your manager, Coach Daimatsu?

Kasai: I had a lot of trust and respect for Coach Daimatsu. The team was happy to take direction from him because we trusted him. He was a volleyball player himself when he was a university student. He joined Nichibō after being a soldier in the war. The team and I followed his hard training because of his great human nature. He was a man we could trust and respect as a human being. Whenever our team won, we were convinced that his hard training was the right way to go, and so we would practice and train hard again, and then we would win again. There was a very close bond between him and the team.

Macnaughtan: Why were you chosen to be the Nichibō (and later Olympic) team captain?

Kasai: I was chosen to be Nichibō captain in 1956, because I was the eldest player in the team. The other members of the team were great because they made a lot of effort to unite around me. There was good team work.

Macnaughtan: Was it just because you were the eldest player? Or were you also the strongest player?

Kasai: (Laughs) It was because I was the eldest player. The next eldest player was four years younger than me, so others were a bit afraid of me. But, I played in the position of 'setter', so I had the ball most often.

Macnaughtan: The Japanese women's volleyball team was given the nickname 'The Oriental Witches' (東洋の魔女) by the media. How did this nickname make you feel?

Kasai: We were given that nickname while abroad after winning the world championships in 1962. The Soviet women's team was thought to be the strongest team in the world, but the Japanese team, coming from such a small country, beat the USSR. So, it was said that the 
Japanese team must have been using some form of magic. The nickname was first used by the Russian media - in the newspaper, Pravda - and not by the Japanese media initially. In Japan, 'witch' (魔女) is a scary thing. But the nickname wasn't meant to reflect this. It was a word to describe our volleyball play, which had never been seen before; techniques such as 'receive and rotate' (回転レシーブ). ${ }^{19}$

Macnaughtan: Did you feel any expectation or pressure from the Japanese public before and during the Olympics in 1964 ?

Kasai: After returning from our victory at the world championships in Moscow in 1962, myself and other team members had intended to stop playing volleyball because of our age. But in May 1962, it was decided that women's volleyball would be an Olympic event for the first time at the Tokyo Olympics in 1964. The Japanese media asked our team what we thought about the decision of volleyball becoming an Olympic event. I answered decisively to the media that our goal was not the Olympics, but the world championships, and that I had already decided to retire after Moscow in October 1962. Other members of the team thought the same as I did. But, I was persuaded from all around me to continue to play for the Olympics. It was not an easy decision to make, because when I thought about all the hard training that we had undertaken during 1960-1962, and about the even harder training that there would have to be to head towards the Olympics, I felt I just could not continue because of my age. But the public did not allow me to retire. So I decided to carry on for another two years to the Olympics in 1964. From that moment on, in 1962, the Japanese women's volleyball team was expected to win the gold medal. The only way to respond to the public expectation was to win the gold medal. We players all practiced desperately in order to respond to the public. I was happy that I was able to win the gold medal and meet that public expectation.

Macnaughtan: Do you think your Olympic victory made volleyball more popular in Japan, particularly for women?

Kasai: One of the biggest influences after the Tokyo Olympics was the wide spread of mamasan volleyball (mother's volleyball). Before 1964, housewives (shufu) concentrated on housework and looking after children, and they lived together with their parents in law. It was unthinkable that a Japanese housewife would do sports, or have a job outside the home. But the victory at the Tokyo Olympics encouraged women to take up sports outside the home. Volleyball doesn't need much equipment - just a ball and a net. By 1968, a mama-san volleyball national competition was organised in Tokyo. It was very rapid. Mama-san volleyball is still popular everywhere today. There are some women who started playing mama-san volleyball in those early days who are still playing now. There are national competitions every year called Isoji (五十路) for the over 50's, Kotobuki (寿) for the over 60's and Ofuku (おふく） for the over 70's. I have been involved with all of these.

\footnotetext{
${ }^{19}$ Amongst Coach Daimatsu's training techniques, the most infamous move was the technique known as 'receive and rotate' (回転レシーブ), which became the signature move of the Nichibō Kaizuka team and later the Olympic team. This move involved receiving the ball without touching one's bottom on the floor and then rotating immediately into a defence position.
} 
Macnaughtan: Volleyball was also popularised in television programmes and by the media?

Kasai: The mass media was very influential. The numbers of those playing volleyball across Japan greatly increased because of its presence on TV and in newspapers and magazines. The TV programme 'V is our Sign' (サインは V) was about a fictional volleyball team, which was based on our team. 'Attack No. 1' (アタック No.1) was a popular animation series. ${ }^{20}$ These were greatly influenced by the gold medal at the Olympics. I couldn't have imagined that these sorts of things would happen afterwards. I just did my very best, in something that I really liked.

Macnaughtan: What impact did winning the gold medal at the 1964 Olympics have on your life?

Kasai: The gold medal changed my life a lot. My subsequent 48 years have been a really happy life. Many people who watched TV that day and cheered for the volleyball team in the Olympics, have now passed away. But I am still remembered by a lot of people when I attend volleyball classes and activities all over Japan. The fact that the Olympics were held in Japan had a huge impact. People all over Japan watched the games on TV. Even people who didn't have a TV watched them somewhere. The viewing rate of our final match is still unbeatable. It has been 48 years since then, but I am still recognised everywhere - in the train, on the streets or in the department store. I'm very grateful. I think that I am the luckiest volleyball player in the world. Because my team won the gold medal at both the World championships and at the Olympic Games, we were chosen as the best team of the twentieth century by the Volleyball Hall of Fame in the USA. However, I have an ordinary life. I used to live with my parent's in law when I married. My husband passed away fifteen years ago, so now I live with my son. I'm just an ordinary 'grandmother' (普通のお婆さん) who does the shopping and the cooking etc.

Macnaughtan: Do you have any grandchildren?

Kasai: No, I don’t have grandchildren. So, I'm not a 'grandmother' (のお婆さん). I am a mother (お母さん). I am still healthy, even though I will turn 79 years old in July. My ability to still yell in a big voice was from all the years spent training and practicing volleyball in noisy gymnasiums.

Macnaughtan: Do you keep in contact with any of the other original team members? Or with Nichibō (Unitika)?

20 'V is our Sign (サインは V - the V representing Victory) and 'Attack No. 1' (アタック No.1) both started as manga cartoons initially in 1968 and became very popular. 'V is our Sign' launched as a TV series the following year in 1969 and became a hit drama, popular amongst a wide audience ranging from children to adults, and boasting average viewing ratings of $32.3 \%$. 'Attack No.1' became an animated TV series in 1969, and later a liveaction drama series in 2005 . 
Kasai: I still keep in contact with other members of the Olympic team. I sometimes telephone them to see what is going on in their lives and share news. Four of them live in the Kansai area in Osaka and in Shiga - so when I go to Osaka we all get together. When we meet up, it's just like the old days and we're still all the same. We have a very strong bond. Since 2000, Unitika (Nichibō) no longer has a volleyball team. ${ }^{21}$ At that time, in 2000, all the players in the Unitika team moved over to the Toray team, but they have all retired now. Current women's volleyball teams in Japan are teams such as the Toray Arrows - a chemical fibre company - and the Hisamitsu Springs - a pharmaceutical company. The textile spinning companies have all faded away. Volleyball is still a corporate sport - rather than a sponsorship sport - in Japan. The corporations have volleyball teams for their own advertisement. It can be a good advertisement for the company if their volleyball team is strong.

Our interview winds up with me thanking Kasai for her time and remarking on how vibrant she has come across during our interview.

Kasai: You know, health is the most important thing in life. I am very thankful for my good health. I have been healthy since birth, and I became stronger both physically and mentally because of all my volleyball training. I've never been to hospital except to give birth to my three children. Of course, I'm almost 79 years old, so I wonder about my health in the future, but I want to live my life to the utmost and in the present. When my life does end, I want to be thinking of how wonderful that life was.

${ }^{21}$ Nichibō changed its name to Unitika in 1969, following a merger with Nippon Rayon. 